\title{
Kadar Lipid Darah Mencit Betina Middle-Aged Galur Swiss Webster setelah Pemberian Jus Buah Pare (Momordica charantia L.)
}

\author{
Rita Shintawati, Hernawati, Desi Indraswati \\ Jurusan Biologi-Fakultas Pendidikan MIPA \\ Universitas Pendidikan Indonesia
}

\begin{abstract}
Abstrak
Penuaan sistem reproduksi (ovarian aging) telah diketahui pada beberapa spesies vertebrata dan manusia yang ditandai dengan kadar estrogen yang rendah. Hal ini berhubungan dengan peningkatan jumlah lipid (obesitas) dan sejumlah penyakit metabolik seperti hiperlipidemia, penyakit kardiovaskular, dll. Buah pare Momordica charantia L.) memiliki banyak manfaat yang menguntungkan bagi kesehatan manusia, seperti efek hipoglikemik, antioksidan, hipokolesterolemik, dan hipotrigliseridemik. Tujuan penelitian untuk mengetahui kadar lipid darah mencit pada usia middle-aged setelah diberikan jus buah pare. Dilakukan uji eksperimental pada Maret-April 2010 di Laboratorium Fisiologi Universitas Pendidikan Indonesia dan Kedokteran Hewan IPB terhadap 25 mencit galur Swiss Webster betina usia 10 bulan (middle-aged) yang terbagi dalam lima kelompok perlakuan berbeda (kontrol positif, kontrol negatif, $0,5 \mathrm{~mL} / 40 \mathrm{~g} \mathrm{BB}, 1,0 \mathrm{~mL} / 40 \mathrm{~g} \mathrm{BB}$, dan 1,5 mL/40 g BB) yang diberikan jus buah pare selama 10 hari. Penelitian menggunakan rancangan acak lengkap. Hasil penelitian menunjukkan bahwa jus buah pare dapat menurunkan bobot badan mencit secara bermakna $(\mathrm{p}<0,05)$ pada semua dosis. Jus buah pare tidak dapat menurunkan kadar kolesterol total, tetapi meningkatkan kadar HDL $(p<0,05)$ pada semua dosis perlakuan. Pada parameter lain, jus buah pare dapat menurunkan kadar trigliserida pada dosis $1,5 \mathrm{~mL} / 40 \mathrm{~g} \mathrm{BB}(\mathrm{p}<0,05)$ dan menurunkan kadar LDL pada dosis 0,5 mL/40 g BB (136,49 mg/dL). Simpulan, jus buah pare dapat menstabilkan kadar trigliserida dan LDL kolesterol pada dosis $0,5 \mathrm{~mL} / 40 \mathrm{~g} \mathrm{BB}$ serta meningkatkan HDL kolesterol, tetapi tidak berpengaruh pada penurunan kadar kolesterol total. [MKB. 2011;43(2):93-7].
\end{abstract}

Kata kunci: Buah pare, kadar lipid darah, mencit betina middle-aged

\section{Lipid Level of Middle-Aged Female Mice Swiss Webster after Pare Juice Momordica charantia L. Administration}

\begin{abstract}
Ovarian aging has been noted in some vertebrate animals and human being, indicated by low estrogen level. This is related to enhancement of lipid (obesity) and some metabolic diseases such as hyperlipidemia, cardiovascular disease, etc. Pare juice (Momordica charantia L.), contains of abundant advantageous bioactivities, such as hypoglycemic effect, antioxidant, hypocholesterolemic, and hypotrigliseridemic. This research purposed was to determine blood lipid levels of mice at the age of middle-aged after being given pare juice. The experimental animal used 25 females mice of 10 months old (middle-aged) on March-April 2010 at Physiology Laboratory Universitas Pendidikan Indonesia and Veteriner Medicine IPB, divided into five different treatment groups (controle positive, controle negative, $0.5 \mathrm{~mL} / 40 \mathrm{~g} \mathrm{bw}, 1.0 \mathrm{~mL} / 40 \mathrm{~g} \mathrm{bw}$, and $1.5 \mathrm{~mL} / 40 \mathrm{~g} \mathrm{bw}$ ) which were fed with pare juice for 10 days. Completely randomized design was used in this research. Results showed that pare juice reduced lower body weight of mice $(p<0.05)$ at all doses. Pare juice did not reduce total cholesterol levels, but increased $\operatorname{HDL}(p<0.05)$ at all doses. Other parameters to pare juice reduced triglyceride levels at doses of $1.5 \mathrm{~mL} / 40 \mathrm{~g} \mathrm{BW}(\mathrm{p}<0.05)$ and LDL levels at dose $0.5 \mathrm{~mL} / 40 \mathrm{~g} \mathrm{BW}(136.49 \mathrm{mg} / \mathrm{dL})$. In conclusions, pare juice can stabilize triglyseride and LDL cholesterol level at dose $0.5 \mathrm{~mL} / 40 \mathrm{~g} \mathrm{BW}$ and increases HDL cholesterol, but has no influence to total cholesterol. [MKB. 2011;43(2):93-7].
\end{abstract}

Key words: Blood lipid, middle-aged female mice, pare fruit

Korespondensi: Dr. Rita Shintawati, M.Kes, Biologi-FPMIPA Universitas Pendidikan Indonesia, jalan Dr. Setiabudhi 229 Bandung, telepon(022) 2013163, mobile 08562012168,e-mail: rita_shintawati@yahoo.co.uk 


\section{Pendahuluan}

Penuaan sistem reproduksi (ovarian aging) telah diketahui pada beberapa spesies vertebrata dan manusia. ${ }^{1,2}$ Tikus percobaan mengalami penurunan fungsi ovarium pada usia 6-18 bulan yang ditandai dengan kadar estrogen yang rendah. Penurunan fungsi sistem reproduksi berhubungan dengan peningkatan jumlah lipid (obesitas) dan sejumlah penyakit metabolik, seperti dislipidemia, penyakit kardiovaskular, hipertensi, dan resistensi insulin. ${ }^{3}$

Kadar kolesterol meningkat sesuai dengan bertambahnya usia seorang wanita. Hal tersebut dipengaruhi oleh faktor hormonal, yaitu semakin menurunnya kadar estrogen. Telah diketahui bahwa estrogen dapat meningkatkan high density lipoprotein (HDL) kolesterol dan menurunkan low density lipoprotein (LDL) kolesterol, di samping sebagai antioksidan dalam mencegah proses oksidasi LDL. ${ }^{4}$

Pare (Momordica charantia L.) merupakan salah satu tanaman tropis yang banyak terdapat di Asia, India, Afrika Timur, dan Amerika Selatan yang dimanfaatkan untuk mengobati diabetes melitus, sebagai antioksidan, hipokolesterolemia, dan hipotrigliseridemia. ${ }^{5,6} \mathrm{Di}$ dalam buah pare banyak mengandung bahan aktif seperti cucurbitasin (zat pahit), momordikosid, momorkarin, momordisin, momordin, asam trikosapar, resin, asam resina, vitamin $\mathrm{A}, \mathrm{B}$, dan $\mathrm{C}$, karantin, hydroxytryptamine, dan saponin. ${ }^{7,8}$ Telah dilakukan penelitian mengenai ekstrak buah pare dalam menurunkan kadar gula darah dan kolesterol total, trigliserida, LDL, serta meningkatkan HDL darah mencit. ${ }^{7,8}$

Pada wanita usia menjelang menopause terdapat masalah tersendiri. Berbagai upaya dilakukan untuk mengurangi permasalahan menjelang menopause, misalnya mengonsumsi buah pare yang telah diketahui memiliki peran fitosterol dan antioksidan. Berdasarkan hal tersebut, tujuan penelitian adalah untuk mengetahui kadar lipid darah mencit pada usia middle-aged setelah diberikan jus buah pare.

\section{Metode}

Penelitian ini merupakan uji eksperimental laboratorik dengan menggunakan rancangan acak lengkap (RAL) yang dilakukan pada bulan Maret-April 2010 di Laboratorium Fisiologi Universitas Pendidikan Indonesia (UPI) dan Fakultas Kedokteran Hewan Institut Pertanian Bogor (FKH-IPB). Hewan coba yang digunakan pada penelitian ini adalah mencit (Mus musculus) betina galur Swiss Webster usia 10 bulan sebanyak 25 ekor yang diperoleh dari Sekolah Ilmu dan Teknologi Hayati, Institut Teknologi Bandung.
Hewan percobaan yang digunakan dikelompokkan secara acak menjadi lima kelompok, yaitu kontrol negatif, kontrol positif, dan tiga kelompok perlakuan. Kontrol negatif hanya diberi pakan standar CP551, air minum ad libitum, tanpa perlakuan jus buah pare. Kontrol positif diberi pakan induksi dan air minum, tanpa perlakuan jus buah pare. Tiga kelompok lain diberi pakan induksi, air minum, dan perlakuan jus buah pare dengan dosis jus yang bervariasi $(0,5 \mathrm{~mL} / 40 \mathrm{~g} \mathrm{BB}$, $1,0 \mathrm{~mL}$, dan $1,5 \mathrm{~mL} / 40 \mathrm{~g}$ BB mencit).

Pembuatan pakan induksi dilakukan dengan mencampur pakan standar CP551 dan lemak sapi yang dibuat supaya pakan tersebut memiliki kadar lemak yang berlebih daripada kadar pakan standar. Pakan induksi tersebut dibuat dengan resep perbandingan pakan dan lemak sapi sebesar 7:3.9

Pembuatan jus buah pare sebagai berikut: sebanyak $200 \mathrm{~g}$ buah pare ditimbang, bagian biji dibuang kemudian dijus dengan menggunakan juicer, ampas yang dihasilkan dibuang. Sari jus tersebut siap digunakan untuk perlakuan.

Penentuan dosis jus buah pare didasarkan pada dosis aman jus segar buah pare yang dikonsumsi manusia, yaitu 50-100 mL. ${ }^{10}$ Pemberian dosis jus buah pare untuk mencit dihitung dengan menggunakan tabel perbandingan luas permukaan tubuh hewan percobaan untuk konversi dosis manusia dengan berat badan (BB) manusia $70 \mathrm{~kg}$ ke bobot badan mencit $20 \mathrm{~g}^{6}$ adalah 0,0026 . Dalam penelitian ini akan digunakan dosis tertinggi, yaitu $100 \mathrm{~mL}$. Penghitungan konversi dosis jus buah pare adalah sebagai berikut: $100 \mathrm{~mL} \times 0,0026=$ $0,26 \mathrm{~mL}$. Apabila bobot badan $40 \mathrm{~g}$, maka dosis tersebut adalah $0,52 \mathrm{~mL}$ atau $\approx 0,5 \mathrm{~mL} / 40 \mathrm{~g}$.

Setelah proses pemberian pakan induksi selama satu minggu penuh, setiap kelompok perlakuan diberi jus buah pare dengan cara dicekok dengan dosis yang telah ditentukan. Jus tersebut diberikan selama 10 hari.

Setelah tahap perlakuan, dilakukan pengambilan sampel darah dengan cara mengambil darah dari jantung mencit yang telah dibius dengan eter. Darah ditampung dalam tabung sentrifus, kemudian didiamkan selama 15 menit dan disentrifugasi selama 20 menit dengan kecepatan 3.000 rpm. ${ }^{11}$ Serum darah yang telah diperoleh kemudian dianalisis kadar lemaknya di laboratorium FKHIPB. Data hasil penelitian kemudian dianalisis varian satu arah (one way ANOVA/analysis of variance) yang dilanjutkan dengan uji wilayah berganda Duncan dengan tingkat kepercayaan 95\%.

\section{Hasil}

Secara keseluruhan, kadar lipid darah mencit akibat perlakuan variasi dosis jus buah pare yang 
meliputi kadar kolesterol total, trigliserida, LDL dan HDL kolesterol tersaji pada Tabel 1, sedangkan bobot badan mencit dapat dilihat pada Tabel 2 .

Pada Tabel 1 dapat dilihat bahwa pemberian jus buah pare pada semua dosis perlakuan belum mampu menurunkan kadar kolesterol total darah mencit betina usia 10 bulan (middleaged) $(\mathrm{p}<0,05)$. Kelompok jus buah pare dengan dosis $0,5 \mathrm{~mL} / 40 \mathrm{~g}$ BB dapat menurunkan kadar trigliserida, LDL kolesterol, dan meningkatkan kadar HDL kolesterol darah secara nyata $(p<0,05)$. Kadar trigliserida paling rendah dicapai dengan dosis perlakuan $1,0 \mathrm{~mL} / 40 \mathrm{~g} \mathrm{BB}$, lebih rendah dibandingkan dengan kontrol negatif, diikuti dosis $1,5 \mathrm{~mL} / 40 \mathrm{~g}$ BB. Dosis $0,5 \mathrm{~mL} / 40$ g BB merupakan satu-satunya dosis yang mampu menurunkan kadar LDL kolesterol, meskipun belum dapat menyamai kontrol negatif. Perlakuan jus buah pare tampaknya meningkatkan kadar HDL kolesterol seiring meningkatnya dosis perlakuan $(\mathrm{p}<0,05)$.

Tabel 2 menunjukkan hasil pengukuran bobot badan mencit setelah pemberian jus buah pare. Setelah diberikan jus buah pare bobot badan ratarata mencit menurun. Penurunan bobot badan disebabkan perlakuan semua dosis jus buah pare; dosis $0,5 \mathrm{~mL} / 40 \mathrm{~g}$ BB memperlihatkan penurunan bobot badan paling banyak $(\mathrm{p}<0,05)$ dibandingkan dengan dosis lainnya.

\section{Pembahasan}

Jus buah pare yang diberikan pada mencit betina usia 10 bulan pada penelitian ini, tampaknya belum mampu menurunkan kadar kolesterol total. Berbeda dengan penelitian-penelitian serupa sebelumnya, pare dapat menurunkan kadar kolesterol.12-14 Hal ini diduga disebabkan metabolisme lemak, khususnya kolesterol pada mencit usia middleaged berbeda dengan metabolisme kolesterol pada mencit usia muda. Kolesterol dalam tubuh dapat berasal dari dua sumber, yaitu eksogen/makanan dan endogen/sintesis dalam tubuh sendiri. ${ }^{15-17}$ Metabolisme kolesterol sangat dipengaruhi oleh faktor hormonal, ${ }^{15-17}$ khususnya estrogen dan progesteron. Pada usia middle-aged, kadar kedua hormon tersebut mengalami penurunan dan sebagai kompensasi, tubuh berusaha meningkatkan produksi kedua hormon tersebut dengan meningkatkan cadangan lemak maupun kolesterol dalam tubuh sebagai bahan baku pembuatan hormon steroid. Dengan demikian, seiring dengan meningkatnya usia, cadangan lemak ataupun produksi kolesterol endogen tubuhpun meningkat, bahkan tanpa peningkatan asupan lemak dari makanan, seperti kadar kolesterol kelompok kontrol negatif yang tanpa pemberian pakan tinggi lemak $(71,33 \mathrm{mg}$ dL). Pakan tinggi lemak pada kelompok perlakuan tampaknya memperburuk metabolisme kolesterol pada usia middle-aged, sehingga meningkatkan kadar kolesterol lebih tinggi dari normal, meskipun di dalam buah pare mengandung bahan-bahan aktif (momordisin, momordin, asam trikosapat, resin, asam resinat, saponin, vitamin $\mathrm{A}, \mathrm{B}$, dan $\mathrm{C}$, serta lemak tidak jenuh). Pada penelitian ini buah pare tidak mampu menurunkan kadar kolesterol, juga mungkin disebabkan kadar jus buah pare yang kurang pekat, sehingga zat aktif yang terkandung dalam jus buah pare pun kurang banyak, seperti

Tabel 1 Kadar Lipid Darah Mencit setelah Perlakuan Jus Buah Pare

\begin{tabular}{lcccc}
\hline \multicolumn{1}{c}{ Perlakuan } & $\begin{array}{c}\text { Kolesterol Total } \\
(\mathbf{m g} / \mathbf{d L})\end{array}$ & $\begin{array}{c}\text { Trigliserida } \\
(\mathbf{m g} / \mathbf{d L})\end{array}$ & $\begin{array}{c}\text { LDL Kolesterol } \\
(\mathbf{m g} / \mathbf{d L})\end{array}$ & $\begin{array}{c}\text { HDL Kolesterol } \\
(\mathbf{m g} / \mathbf{d L})\end{array}$ \\
\hline Kontrol negatif & $71,33 \pm 21,01^{\mathrm{a}}$ & $87,92 \pm 27,73^{\mathrm{a}}$ & $129,69 \pm 37,37^{\mathrm{a}}$ & $40,57 \pm 13,88^{\mathrm{a}}$ \\
Kontrol positif & $162,04 \pm 19,62^{\mathrm{b}}$ & $212,94 \pm 70,47^{\mathrm{b}}$ & $268,29 \pm 63,24^{\mathrm{b}}$ & $56,20 \pm 26,66^{\mathrm{ab}}$ \\
Pare 0,5 mL/40 g BB & $166,30 \pm 17,73^{\mathrm{b}}$ & $102,76 \pm 24,28^{\mathrm{a}}$ & $136,49 \pm 52,01^{\mathrm{a}}$ & $49,44 \pm 16,44^{\mathrm{ab}}$ \\
Pare 1,0 mL/40 g BB & $169,50 \pm 23,60^{\mathrm{b}}$ & $78,22 \pm 22,83^{\mathrm{a}}$ & $237,85 \pm 67,20^{\mathrm{b}}$ & $67,96 \pm 19,20^{\mathrm{bc}}$ \\
Pare 1,5 mL/40 g BB & $150,04 \pm 28,02^{\mathrm{b}}$ & $98,88 \pm 26,33^{\mathrm{a}}$ & $279,46 \pm 32,60^{\mathrm{b}}$ & $83,88 \pm 10,50^{\mathrm{c}}$ \\
\hline
\end{tabular}

Keterangan: Angka yang diikuti oleh huruf yang berbeda pada kolom yang sama menunjukkan adanya perbedaan nyata $(p<0,05)$

Tabel 2 Bobot Badan Mencit setelah Perlakuan Jus Buah Pare

\begin{tabular}{ll}
\hline Perlakuan & Bobot Badan (gram) \\
\hline Kontrol negatif & $36,86 \pm 1,82^{\mathrm{a}}$ \\
Kontrol positif & $45,64 \pm 0,87^{\mathrm{b}}$ \\
Pare $0,5 \mathrm{~mL} / 40 \mathrm{~g} \mathrm{BB}$ & $29,94 \pm 1,08^{\mathrm{a}}$ \\
Pare $1,0 \mathrm{~mL} / 40 \mathrm{~g} \mathrm{BB}$ & $33,50 \pm 0,85^{\mathrm{a}}$ \\
Pare $1,5 \mathrm{~mL} / 40 \mathrm{~g} \mathrm{BB}$ & $35,16 \pm 1,32^{\mathrm{a}}$ \\
\hline
\end{tabular}

Keterangan: Angka yang diikuti oleh huruf yang berbeda pada kolom yang sama menunjukkan adanya perbedaan nyata $(\mathrm{p}<0,05)$ 
pada dosis jus buah pare tertinggi, yaitu $1,5 \mathrm{~mL} / 40$ g BB dapat menurunkan kadar kolesterol walaupun belum mencapai kadar normal.

Hal lain yang mungkin terjadinya kadar kolesterol yang tinggi pada penelitian ini adalah waktu pengambilan sampel darah. Diduga saat pengambilan sampel darah terlalu dini karena proses lipolisis sedang aktif terjadi. ${ }^{12,13}$ Proses lipolisis yang terjadi akibat pemberian jus buah pare akan meningkatkan mobilitas asam lemak bebas, kolesterol, dan LDL kolesterol ke dalam darah pada awalnya yang selanjutnya kadar lipid tersebut akan kembali normal setelah proses lipolisis selesai. Hal ini ditandai dengan kembalinya kadar lipid ke kadar normal, tetapi proses tersebut memerlukan waktu.

Berbeda dengan kolesterol total, jus buah pare pada semua dosis perlakuan dapat menurunkan kadar trigliserida darah, hal ini sesuai dengan penelitian sebelumnya. ${ }^{12-14}$ Dosis yang memberikan pengaruh paling baik adalah $1 \mathrm{~mL} / 40 \mathrm{~g} \mathrm{BB}$ dan $1,5 \mathrm{~mL} / 40 \mathrm{~g}$ BB. Hal ini disebabkan karena buah pare dapat meningkatkan metabolisme trigliserida ${ }^{7}$ dengan memacu sekresi katekolamin plasma $^{13}$ yang selanjutnya meningkatkan lipolisis sebagai akibat meningkatnya aktivitas enzim oksidasi lipid dalam jaringan adiposa. ${ }^{12}$

Seperti halnya kadar kolesterol total, efek pemberian jus buah pare pada dosis lebih tinggi tidak mampu menurunkan kadar LDL kolesterol (Tabel 1), kecuali perlakuan $0,5 \mathrm{~mL} / 40 \mathrm{~g}$ BB meskipun tidak mencapai kadar normal. Berbeda dengan hasil penelitian terdahulu, LDL kolesterol dapat distabilkan dengan pemberian buah pare. ${ }^{12-14}$ Diduga hal ini pun disebabkan perbedaan metabolisme LDL kolesterol pada mencit usia middle-aged dibandingkan dengan mencit usia muda. Oleh karena kadar LDL kolesterol tinggi, maka kolesterol total pun tetap tinggi. Pada kelompok perlakuan dengan dosis lebih tinggi $(1,0 \mathrm{~mL}$ dan $1,5 \mathrm{~mL} / 40$ g BB), tidak mampu menurunkan kadar LDL kolesterol, hal tersebut diduga disebabkan oleh efek salah satu bahan aktif dari buah buah pare yang berlawanan terhadap kadar kolesterol, terutama LDL kolesterol. Diduga jus buah pare dengan dosis lebih tinggi dapat menurunkan fertilitas mencit ataupun penurunan kadar estrogen serta progesteron 18,19 dan menyebabkan keadaan penuaan sistem reproduksi yang salah satunya ditandai dengan peningkatan lipid darah serta penumpukan lemak di daerah abdominal. ${ }^{16}$

Pemberian jus buah pare pada mencit betina usia 10 bulan dapat meningkatkan kadar HDL kolesterol pada semua dosis perlakuan sesuai dengan penelitian sebelumnya. ${ }^{4-7}$ Apabila dilihat kadar HDL rata-rata, maka semakin tinggi dosis jus buah pare yang diberikan, semakin tinggi kadar HDL kolesterol dalam darah. Hal tersebut memberikan pengaruh positif bagi tubuh terutama untuk menjaga keseimbangan kadar kolesterol dalam tubuh. Peningkatan kadar HDL kolesterol ini sangat mungkin disebabkan kandungan antioksidan, vitamin A, B1, B3, C, likopen, lutein, dan zeaxantin yang terkandung dalam buah pare. ${ }^{10}$ Tampaknya usia middle-aged tidak berpengaruh menurunkan kadar HDL kolesterol, sehingga pemberian jus buah pare akan langsung meningkatkan kadar HDL kolesterol.

Hasil pengukuran bobot badan yang diperoleh menunjukkan bahwa jus buah pare mampu menurunkan bobot badan mencit betina usia 10 bulan pada semua dosis perlakuan $(p<0,05)$. Kelompok perlakuan yang mengalami penurunan bobot badan paling besar adalah perlakuan 1,5 $\mathrm{mL} / 40 \mathrm{~g} \mathrm{BB}$ (Tabel 2). Salah satu bahan aktif di dalam buah pare adalah cucurbitasin, suatu zat yang dihasilkan buah pare dengan rasa pahit.Akibat bahan aktif tersebut dimungkinkan nafsu makan mencit menjadi berkurang, selain itu jus buah pare dapat menurunkan kadar trigliserida seperti juga yang terjadi pada penelitian ini. Penurunan trigliserida akan menurunkan cadangan lemak tubuh, akibatnya bobot badan pun menurun. Hasil penelitian ini mendukung penelitian sebelumnya ${ }^{12-14,16}$ yang menyatakan bahwa buah pare dapat mengontrol bobot badan. Hal ini disebabkan oleh bioaktivitas buah pare meningkatkan oksidasi lipid, sehingga menyebabkan akumulasi jaringan lemak menurun yang selanjutnya menurunkan bobot badan.

Terdapat keterkaitan berat badan dan trigliserida dengan HDL kolesterol. Apabila berat badan dan trigliserida meningkat, maka kadar HDL kolesterol cenderung turun. ${ }^{7,8}$ Hal tersebut selaras dengan penelitian ini, bobot badan dan kadar trigliserida menurun sementara kadar HDL kolesterol meningkat, tetapi ternyata peningkatan HDL kolesterol belum mampu untuk menurunkan kadar LDL berlebih; hanya dosis $0,5 \mathrm{~mL} / 40 \mathrm{~g} \mathrm{BB}$ yang mampu menurunkan kadar LDL. Menurut Adimunca dan Nainggolan, ${ }^{7}$ buah pare dapat meningkatkan aktivitas reseptor LDL secara in vivo. Pada penelitian ini faktor senyawa antifertilitas tampaknya mendominasi untuk meningkatkan LDL darah pada dosis yang lebih tinggi, terlebih akibat faktor menurunnya estrogen dan progesteron.

Simpulan penelitian ini adalah jus buah pare dapat menstabilkan kadar trigliserida dan LDL kolesterol pada dosis $0,5 \mathrm{~mL} / 40 \mathrm{~g}$ BB serta meningkatkan HDL kolesterol, tetapi tidak berpengaruh pada penurunan kadar kolesterol total mencit betina usia 10 bulan.

\section{Daftar Pustaka}

1. Wu JM, Zelinski MB, Ingram DK, Ottinger MA. Ovarian aging and menopause: current 
theories, hypotheses, and research models. Exp Biol Med. 2005;230(11):818-28.

2. Anzalone CR, Hong LS, Lu JKH, LaPolt PS. Influences of aged and ovarian follicular reserve on estrous cycle patterns, ovulation and hormone secretion in the long-evants rat. Biol Reproduction. 2001;64:1056-62.

3. Aleshire MJR, Stanic MD, Hasty AH, Hoyer PB, Brooks HL. Loss of ovarian function in the VCD mouse-model of menopause leads to insulin resistance and a rapid progression into the metabolic syndrome. Am J Physiol Regul Integr Comp Physiol. 2009;297(3):R587-92.

4. Jones ME, Thorburn AW, Britt KL, Hewitt KN, Wreford NG, Proietto J, dkk. Aromatase-deficient (ArKO) mice have a phenotype of increased adiposity. PNAS. 2000;97(23):12735-40.

5. Abascal K, Yarnell E. Using bitter melon to treat diabetes. Altern Complement Ther Med. 2005;11(4):179-84.

6. Sutyarso S, Adimunca C. Pengaruh ekstrak buah pare ( $M$. charantia L.) terhadap kadar kolesterol dan gula darah mencit. MKI. 1995;45(12):674-9.

7. Adimunca C, Nainggolan O. Efek buah pare (Momordica charantia L.) terhadap profil lipid serum tikus putih jantan strain Wistar derived LMR. J Cermin Dunia Kedokteran. 2009;36(2):97-100.

8. Fernandes NPC, Lagishetty CV, Pdana VS, Naik SR. An experimental evaluation of the antidiabetic and antilipidemic properties standardized momordica charantia fruit extract. BMC Complementary Alternative Med. 2007;7(29):1-8.

9. Mulyadi IT. Gambaran histologis organ hati mencit (Mus musculus L.) betina galur Swiss Webster setelah pemberian pektin kulit jeruk bali (Citrus grandis) (Skripsi). Bandung: Institut Teknologi Bandung; 2008.

10. Raman A, Lau C. Anti-diabetic properties dan phytochemistry Momordica charantia L . (Curcurbitaceae). Phytomedicine. 1996;2: 349-52.

11. Dachriyanus K, Delpa U, Oktaria R, Ernas O, Mukhtar MH. Uji efek A-mangostin terhadap kadar kolesterol total, trigliserida, kolesterol HDL dan kolesterol LDL darah mencit putih jantan serta penentuan lethal dosis $50\left(\operatorname{Ld}_{50}\right)$. Jurnal Sains Teknologi. 2007;12(2):64-72.

12. Chen Q, Chan LLY, Li ETS. Bitter melon (Momordica charantia) reduces adiposity, lowers serum insulin and normalizes glucose tolerance in rats fed a high fat diet. J Nutr. 2003;133(11):1088-93.

13. Chen Q, Li ETS. Reduced adiposity in bitter melon (Momordica charantia) fed rats is associated with lower tissue triglyceride and higher plasma catecholamines. Br J Nutr. 2005;93(5):747-54.

14. Chan LLY, Chen Q, Go AGG, Lam EKY, Li ETS. Reduced adiposity in bitter melon (Momordica charantia) fed rats is associated with increased lipid oxidative enzyme activities and uncoupling protein expression. J Nutr. 2005;135(11):2517-23.

15. Galman C, Matasconi M, Persson L, Parini P, Angelin B, Rudling M. Aged induced-hypercholesterolemi in the rat relates to reduced elimination but not increased intestinal absorption of cholesterol. Am J Physiol Endocrinol Metab. 2007;293(3):E737-42.

16. Parini P, Angelin B, Rudling M. Cholesterol and lipoprotein metabolism in aging: reversal of hypercholesterolemia by growth hormone treatment in old rats. Arterioscler Thromb Vas Bio. 1999;19(4):832-9.

17. Metz A, Reinert K, Madörin M, Götz U. Aged dependence of betalipoproteins in comparison with cholesterol and triglycerides in the serum of SPF rats. Arzneimittelforschung. 1981;31(5):809-13.

18. Muzajjanah. Pengaruh pemberian ekstrak biji dan daging buah pare (Momordica charantia L.) terhadap kesuburan mencit betina strain Swiss Webster. 1998. (diunduh 27 Oktober 2009). Tersedia dari: http://www.digilib.ui. ac.id/opac/themes/libri2/

19. Hernawati, Priyandoko D. Antifertilitas ekstrak buah pare (Momordica charantia L.) pada mencit Swiss Webster betina. Seminar Lokakarya. UPI: 2005. 